\title{
Evaluating the Factors Affecting in Divorce in the City of Mahabad
}

\author{
Ali Mostafaei \\ Department of Psychology, Payam-e-Noor University, Tehran, IR. Iran. \\ http://dx.doi.org/10.13005/bbra/2042
}

(Received: 10 January 2016; accepted: 09 February 2016)

\begin{abstract}
The purpose of this study is to investigate the factors influencing divorce in the city of Mahabad. Methodology is descriptive and ex post facto. Statistical population includes 498 file in the dispute resolution council in year 2011. Among the available files randomly from each season, one month, and in total 125 files were identified. The research instrument was a standard questionnaire with 32 questions. Data were analyzed by frequency and percentage, as well as using the chi-square test. The results showed that most of divorces take place in the first five years after marriage (38.4\%), couples Education below Diploma (60\%), and divorce is more in family's workers $(41.6 \%)$. Chi-square test results showed that communication problem $(60 \%)$, low acquaintance before marriage (59.2\%), aggression and violence, 54.4\%), family intervention (38.4\%), drug addiction $(\mathbf{1 8 . 4 \% )}$, and moral perversion, infidelity, and sexual problems $(12 \%)$ are involved in a divorce. Communication problems and low acquaintance before marriage is significant at level of 0.05 and factors sexual perversion and betrayal, sexual dysfunction, interfering in life, and drug addiction is significant at level of 0.01 , and means that the factors mentioned are effective in the forecast of divorce.
\end{abstract}

Key words: divorce, causes of divorce.

Research on divorce during the past decade has focused on a range of topics, including the predictors of divorce, associations between divorce and the well-being of children and former spouses, and interventions for divorcing couples.

Marriage is perhaps the most commonplace of human social relationships. The interaction of married couples is an everyday occurrence. Today, separation and divorce are common phenomena. Separation appears to be trustworthy road to divorce, rather than reconciliation.

Marriage and the family are sacred in all ages and communities. Thus, always family ties and cohesion in society were protected. In all religions, marriage as an auspicious was emphasized. The marriage has always been comfortable, but the couple's divorce and

\footnotetext{
* To whom all correspondence should be addressed. E-mail: a_mostafaei@pnu.ac.ir
}

separation from each other is very difficult and sometimes impossible. Until recent years, the divorce is still illegal in some communities was considered. At the same time, families in modern societies show that modern families face many challenges within; Child abuse, domestic violence (Fatehi Dehaghani and Nazari, 2012), domestic violence (Parvin,Moin and Rusta, 2010) and divorce Common examples of today's family problems. However, the problem is that divorce occurs and if one need it seeks to identify causal concluded that the causes of divorce are affected by several factors. This means that a set of social, cultural, economic (Banijamali, Nafisi, and Yazdi, 2005) and legal -political cause or contribute to preventing divorce. These factors are of different extents in each community.

At this time, Divorce is crisis that gradually affected the family. According to sociological studies, problems of employment and unemployment, poverty, class level differences, and lack of knowledge about man's demands and 
expectations are another important factor in the requesting of divorce (Forutan and Milani, 2008; Zargar and Nashatdust, 2007).

Researchers cited numerous factors for divorce. Sometimes only one factor could be the reason for a person's divorce, Sometimes several factors are combining to make marriage not continue. In general, factors of divorce in modern societies are cultural differences, sexual incompatibility, and conflict of interest, ethical conflicts, feeling dissatisfaction, guilt, sadness, conflict and internal conflicts.

From one perspective it can be placed in two dimensions, individual and social factors affecting divorce. Social factors as follows: the development of urbanization, industrialization, increase in nuclear families, awareness and women's employment crisis and social revolution, unemployment and poverty pointed out. These factors related to community and from outside affected people. From the personal characteristics and psychological factors that either wife or their family is concerned, Can cited age of marriage, addiction, disagreement, betrayal and superficial love. In a general framework, Factors affecting divorce can be divided into biological (Disproportion age of marriage, disease and infertility), psychosocial and social (Dissatisfaction, lack of coordination among couples, stress and violence), economic (Poverty and lack of financial resources and facilities, stingy man, woman worshiping luxury), and cultural factors.

Various studies have outlined various reasons for divorce that referred to some of them. Various investigations have shown cultural, economic, social factors (Nazok tabar and Habib pour, 2011), attachment style, social skills and personality (Shokr kon, Khojasteh Mehr, Attari, Haghighi and Shehni, 2004) in predicting divorce. In another study (Ahmadi and Moltafet, 2008), the duration of the recognition of difference in age, duration common life was considered the most important factors that predict divorce. The most important ask for divorce attributed to communication problems, addiction, (Fatehi Dehaghani and Nazari, 2012) young age, poverty, meddling of families (Fakhraee and Hekmat, 2009), family violence, unmet the expectations of the couple, the couple's differences of opinion, and family income (Fakhraee and Hekmat, 2009) sexy dissatisfaction (Forutan and Milani, 2008), schemas of mistrust- abuse, stringent criteria and mental illness one From couples. Giasi, Moin, and Rusta (2008) focus on the role of educational differences, and age at divorce. Other studies have shown that more divorced in early years of their marriage, and according to researches average of cohabitation of divorced less than 5 years.

Schoen, Amato, and Rogers (Schoen, Rogersand Amato, 2006) conducted a longitudinal study and concluded that sexual infidelity, jealousy, drink alcohol, overspending, temper tantrums, and aggression are effective in increasing divorce. The phenomenon of divorce has for women more negative consequences (Parvin, Kalantari, Davoodi , Mohammadi (2011). Demographers (Amato, 2015) attributed the women's desire to divorce to increasing economic independence of, loss of income, men without a college education, increased expectations, and social acceptance of divorce. Kalmyn (Kalmijn, 2006) not only concluded that proposers of divorce are usually women, but concluded that social and economic factors affect women more than men. Amato (Amato, 2010) reviewed the divorce; found that Hispanics and non-Hispanics whites $42 \%$ of marriages in the first 15 years ending in divorce, and in African-Americans, 55\% of marriages end in divorce is.

The researcher wants to know whether other factors affecting divorce in the city of Mahabad is differ from other regions of the country or not? What factors contribute to the rising divorce rate?

\section{MATERIALSAND METHODS}

The research method is descriptive of the type of ex post facto. The population consisted of all files in the Dispute Resolution Council of Mahabad in 90 the total number of files was 498 files. Using random sampling, existing files in terms of months of the year, randomly selected: from each season one month, and all files of that month as the sample of the study were studied. The total number in the four months was 125 files.

The research tool is a questionnaire with 32 questions was adopted norm that information about the social, personal and family was included 
in it. Information includes two parts: one part was dedicated to demographic information, and the second part was devoted to information that will examine factors affecting divorce. The second part of two-choice questions was response packet. The questionnaire was developed by psychologists and social workers working with the judiciary and content validity were confirmed by experts and its reliability by using Cronbach's alpha coefficient was calculated 0.72 (Sharifi pour, 2009).

The above table (1) shows the Frequency distribution of duration of marriage with chi-square test results. Chi-square test was used to evaluate significance of the observed frequencies. Chisquare test result shows that the difference between observed frequencies for various duration of marriage is meaningful. Comparison of frequencies and percentages of duration of marriage show that more clients (91 people equivalent to 8.72 ) were less than 10 years. The lowest frequency / percentage related to those who have passed more than 20 years of their marriage (10 person equal 8 percent).

Table 2 shows the Frequency distribution of education level with chi-square test results. Chisquare test was used to evaluate significance of the observed frequencies. Chi-square test result shows that the difference between observed frequencies for education level is meaningful. Comparison of the frequency and percentages show that more clients ( 75 subjects equal to $60 \%$ ) were below Diploma and so it people who have associate and bachelor education with 20 percent in the next row were subjected. The lowest percentage belongs to a group which had M.A and higher.

Table 3 shows the frequency distribution of percentage of job's men with chi-square test

Table 1. Frequency distribution of duration of marriage with chi-square test results

\begin{tabular}{lcccccccc}
\hline & $\begin{array}{c}\text { Below 5 } \\
\text { years }\end{array}$ & $\begin{array}{c}\text { Between } \\
\text { 5to } 10 \\
\text { years }\end{array}$ & $\begin{array}{c}\text { Between } \\
11 \text { to } 20\end{array}$ & $\begin{array}{c}21 \\
\text { To up }\end{array}$ & sum & $X^{2}$ & df & Sig. \\
\hline $\begin{array}{l}\text { Frequency } \\
\text { percent }\end{array}$ & 48 & 43 & 24 & 10 & 125 & 29.53 & 3 & 0.0001 \\
\hline
\end{tabular}

Table 2. Frequency distribution educational level with chi-square test results

\begin{tabular}{|c|c|c|c|c|c|c|c|c|}
\hline & Below diploma & diploma & $\mathrm{BA} / \mathrm{BS}$ & M.A and up & sum & $X^{2}$ & df & Sig. \\
\hline Frequency & 75 & 15 & 25 & 10 & 125 & 85.4 & 3 & 0.0001 \\
\hline percent & 60 & 12 & 20 & 8 & 100 & & & \\
\hline
\end{tabular}

Table 3. The frequency distribution of percentage of job’s men with chi-square test results

\begin{tabular}{lccccccccc}
\hline & Unemployed & worker & farmer & $\begin{array}{c}\text { Artisan / } \\
\text { Shopkeeper }\end{array}$ & $\begin{array}{c}\text { Government } \\
\text { jobs }\end{array}$ & sum & $\mathrm{X}^{2}$ & df & Sig. \\
\hline $\begin{array}{l}\text { Frequency } \\
\text { percent }\end{array}$ & 2 & 52 & 43 & 17 & 10 & 125 & 73.68 & 4 & 0.0001 \\
\hline
\end{tabular}

Table 4.The frequency distribution and percentage of income with chi-square test results

\begin{tabular}{lcccccccccc}
\hline & unspecified & $\begin{array}{c}600000 \text { to } \\
1000000\end{array}$ & $\begin{array}{c}1 \text { to } 1.5 \\
\text { million }\end{array}$ & $\begin{array}{c}1.5 \text { to 2 } \\
\text { million }\end{array}$ & $\begin{array}{c}2 \text { to 3 } \\
\text { millio n }\end{array}$ & $\begin{array}{c}\text { More than 3 } \\
\text { million }\end{array}$ & sum & $\mathrm{X}^{2}$ & df & Sig. \\
\hline $\begin{array}{l}\text { Frequency } \\
\text { percent }\end{array}$ & 5 & 15 & 75 & 14 & 4 & 12 & 125 & 68.68 & 5 & 0.0001 \\
\hline
\end{tabular}


Table 5. Observed frequency and percentage couples divorce applicant due to divorcement request

\begin{tabular}{lcccc}
\hline The cause of divorce & $\mathrm{O}$ & $\mathrm{E}$ & $\mathrm{O}-\mathrm{E}$ & Frequency percent \\
\hline Relationship problems & 75 & 62.5 & 12.5 & 60 \\
Moral perversion and betrayal & 15 & 62.5 & -47.5 & 12 \\
Sexy problems & 15 & 62.5 & -47.5 & 12 \\
Family intervention & 48 & 62.5 & -14.5 & 38.4 \\
Aggression and violence & 51 & 62.5 & -11.5 & 54.4 \\
Low familiar before marriage & 74 & 62.5 & -11.5 & 59.2 \\
addiction & 23 & 62.5 & -39.5 & 18.4
\end{tabular}

Table 6. The results of chi-square test for variables in Table 5

\begin{tabular}{lccccccc}
\hline & communicational & $\begin{array}{c}\text { perversion } \\
\text { and infidelity }\end{array}$ & $\begin{array}{c}\text { Sexual } \\
\text { problems }\end{array}$ & intervention & $\begin{array}{c}\text { Aggression } \\
\text { / violence }\end{array}$ & low acquaintance & addiction \\
\hline $\mathrm{X}^{2}$ & 5 & 72.2 & 72.2 & 6.73 & 4.23 & 4.23 & 49.93 \\
$\mathrm{df}$ & 1 & 1 & 1 & 1 & 1 & 1 & 1 \\
sig. & 0.025 & 0.0001 & 0.0001 & 0.009 & 0.040 & 0.040 & 0.0001 \\
\hline
\end{tabular}

results. Chi-square test was used to evaluate significance of the observed frequencies. Chisquare test result shows that the difference between the observed frequencies of various occupations of men is significant. Comparison of frequencies and percentages shows that more clients ( 52 people equal to 41.6 percent) their jobs is worker, and 43 people (equal to 34.4 percent) their jobs were farmer. The lowest percent relate to government jobs.

Table 4 shows the frequency distribution percent of men with chi-square test results. Chisquare test was used to evaluate significance of the observed frequencies. Chi-square test result shows that the difference between the observed frequencies of various incomes of men is significant. Comparison of the frequency and percentages shows that more clients (75 people equal to $60 \%$ ) have incomes between one to one and a half million Tomans, and so it (15 people equivalent to $12 \%$ ) have incomes between six hundred thousand to one million toman. The lowest percent belong to income between 2 to 3 million tomans.

As the results in Table 5 shows the most common cause of divorce are as follows: communication problems (60\%), low acquaintance before marriage (2.59\%), aggression and violence (4.54\%), family intervention (4. 38\%), addiction
(4.18\%), and moral perversion, infidelity, and sexual problems (12\%).

As can be inferred from Table 6, communication problems, and low acquaintance before marriage is significant at levels 0.05 . This means that the difference is not the result of chance and these two factors are effective in predicting the occurrence of divorce. Factors of sexual perversion and betrayal, sexual dysfunction, interfering in life and addiction is significant at levels 0.01 . This means that the mentioned factors are effective in predicting divorce.

\section{DISCUSSION}

The results showed that the majority of clients (91 people equivalent to $8.72 \%$ ) are less than 10 years duration of marriage. The lowest frequency / percentage related to those who have passed more than 20 years of their marriage (10 people equivalents to 8 percent).

These results are consistent with studies of (Zargar and Nashatdust, 2007; Parvin,Moin and Rusta, 2010). Studies show that the majority of divorces occur in the first years of marriage. Probably one of the main reasons for divorce in the first years after the marriage is that in early years of marriage are usually more disputes. Couples are less experienced, and more people 
allow themselves to get involved in their children's lives. Divorce may also occur in subsequent years, with the passage of time, men and women expect from each other that change over time and the other party is not able to respond to it.

Another finding was related to the impact of education on divorce. Chi-square test results showed that the majority of clients (75 people equal to $60 \%$ ) have below diploma, and so it people who have associate and bachelor education by 20 percent in the next row were subjected. The lowest percentage belongs to a group which had graduate education.

The findings with studies (Meshki, Shah Ghasemi, Delshad Nughabiand Moslem, 2012; Fatehi Dehaghani and Nazari, 2012; Shokr kon, Khojasteh Mehr, Attari, Haghighi and Shehni, 2004) are identical. The reason why people with less education are more divorce is linked to several factors: One of the reasons is young age of individuals; low education probably means young age. Probably people who drop out of school, married at a young age. People who marry at a young age are less of mental maturity and therefore during dispute, emotionally encounter and therefore incapable of resolving problems. Another factor is the cultural poverty. People with less education usually have lower levels of socioeconomic as well. The third factor, the less educated children financially and emotionally dependent on their families. These people likely are not able to decide independently and meet their needs and therefore dependent on the ups and downs of their lives to the decisions of others. In contrast, people who are better educated and have more income and jobs may be in terms of age at a higher level. This in turn leads to more mental maturity. So, one of the predictive factors is education level, and taking into account this factor along with others, can be a more successful marriage.

The third finding was related to the job. Analysis of the findings of the jobs (Table 3) showed that the observed frequencies between different jobs of men are significant. Most clients (52 people equivalent to6.41\%) their jobs is worker and (43 people equivalent to $4.34 \%$ ) their jobs agricultural. The lowest percentage related to government occupations.

These results are consistent with the findings of (Banijamali, Nafisi, and Yazdi, 2005; Esaghi, Mohebbi, Sattar, Mohammadi, 2011; Fakhraee and Hekmat, 2009). People who have lowlevel jobs usually are physically very under pressure, they are not financially able to meet the expectations of their wife, culturally belong to families with cultural poverty, probably violent behavior and poor communication skills in them is more. Other findings showed that communication problems (60\%), low acquaintance before marriage (2.59\%), aggression and violence (4.54\%), family intervention (4.38\%), addiction (4.18\%), and moral perversion, infidelity, and sexual problems (12\%) are involved in divorce.

These findings are consistent with previous research (Mohebbi, Sattar, Mohammadi, 2011; Fakhraee and Hekmat, 2009; Shokr kon, Khojasteh Mehr, Attari, Haghighi and Shehni, 2004; Zargar and Nashatdust, 2007). Communication skills are an important part of life in inevitable bitterness and happiness of the people has an important role. Weak interaction decreases the couples understand each other, and makes spouses can support each other and to meet the needs of each other. Undesirable communication patterns can cause major issues remained unresolved and therefore these issues are often repeated source of conflict. Negative interactions provide grounds for divorce. In order to prevent an increase in divorce a useful strategy is teaching communication skills to couples. One more useful way is that these skills be done before marriage. Parent's communication skills play an important role in the development of these skills in their children. Communication skills helps individuals in difficult situations, rather than negative and problematic behaviors, pay more to their manufacturer. Life skills training, rational decisionmaking procedures, methods of coping with the crisis, techniques of control anger and express feelings can have a positive impact on later life.

Drug addiction is waste warmth, adhesion, romance family environment. Anger, hostility, enmity, hatred, jealousy, verbal and physical abuse in the relationship of the couple's marital conflict. Research Esaghi et al (2011) also showed differences couple and a positive attitude toward divorce have a role in predicting divorce. 


\section{REFERENCES}

1. Ahmadi H.; Moltafet. Investigate the factors influencing the tendency of women to divorce (Case Study city Darab H. letter of association of demographic of iran, 2008; 3(5):152- 168.

2. Amato P.R. The Consequences of Divorce for Adults and Children. Retrieved from http:// onlinelibrary.wiley.com/: 10.1111/j.17413737.2000.01269.x/full (2015, 05 06)

3. Amato P.R. Research on Divorce: Continuing Trends and New Developments. Journal of Marriage and Family, 2010; 72( 3): 650-666.

4. Banijamali SH. S., Nafisi G. L R., Yazdi M. The root causes of family disintegration in relation to psychosocial characteristics of boys and girls before marriage. Journal of Education and Psychology martyr Chamran University, 2005; 11, (1, 2): 143-170.

5. Esaghi M.; Mohebbi S.F.; Sattar P.; Mohammadi F. Assess the social factors affecting tendency of women to divorce in Tehran. Women in Development \& Politics, 2011; 10( 3): 97, 124.

6. Fakhraee S.; Hekmat SH.. Social factors affecting on intensity of divorce by women in Sardasht city. Woman and Family Studies, 2009; 2( 7): 103- 120.

7. Fatehi Dehaghani A; Nazari A.M.. Sociological Analysis Factors Affecting Tendency toward divorce in the city of Isfahan. Social Studies Quarterly, 2012, 25, 13-54.

8. Forutan S. K.; Milani M. Determine the prevalence sexual disorders in divorce applicants referred to family court. Medical Daneshvar, a bimonthly Journal of Shahed University, 2008; 16(78): 39-44.

9. Kalmijn M. His or Her Divorce? The Gendered Nature of Divorce and its Determinants. European Sociological Review, 2006; 22( 2):
201- 214.

10. Meshki M ; Shah Ghasemi Z; Delshad Nughabi A.; Moslem A.R. Investigate the situation and factors associated with divorce from the perspective of the couple divorced in years 2007 and 2008. Ofogh Danesh, Journal of Gonabad University of Medical Sciences and Health Services, 2011; 17(1): 35-44.

11. Parvin S, Kalantari A, Davoodi M, Mohammadi F. Emotional Divorce in Tehran City, 2011; 7(4): 57-64

12. Nazok tabar H.; Habib pour K. Factors of divorce in Mazandaran province. Women Strategic Studies, 2011; 14( 53): 87-127.

13. Parvin G; Moin L; Rusta . nvestigate causes of divorce among women referred to family court in Shiraz. Woman andsociety quarterly, 2010; 1(3): 77-104.

14. Sharifi pour H. Normalization of questionnaire of causes of tendency to divorce. NGO of Mahabad population, 2009.

15. Schoen R.; Rogers S.G. ; Amato P.R. Wives' employment and spouses' marital happiness: Assessing the direction of influence using longitudinal couple data. Journal of Family Issues, 2006; 25, 506-528.

16. Shokr kon H.; Khojasteh Mehr R.; Attari Y.; Haghighi J.; Shehni M. Investigate personality traits, social skills, attachment styles, and demographic characteristics as predictors of success and failure in marriage and divorce applicant couples in Ahvaz. Journal of Education and Psychology martyr Chamran University, 2004; 1(3): 13, 1-30.

17. Zargar F.; Nashatdust H. R. Investigate the factors affecting the incidence of divorce in the city of Falavarjan. Family Studies, 2007; 3 (11): 737-749. 